\title{
ANALISIS PENGARUH FAKTOR INTERNAL (INTELEGENSI, MINAT, BAKAT, MOTIVASI, USIA) DAN FAKTOR EKSTERNAL (LINGKUNGAN, PENDIDIKAN, PENGALAMAN, PELATIHAN) TERHADAP PEMAHAMAN PEMBIAYAAN MUDHARABAH DAN MURABAHAH (STUDI PADA BMT DI KABUPATEN KEBUMEN)
}

\begin{abstract}
S
This study was conducted at Baitul Maal Wa Tamwil (BMT) employee who join in BMT Association of Kebumen Regency. This study is entitled 'The Effect Analysis of Internal Factors (Intelligence, Interests, Talent, Motivation, Age) and External Factor (Environment, Education, Experience, Training) toward Understanding of Mudharaba and Murabahah " (Case Study at BMT's employee of Kebumen Regency).

This study aims to determine the BMT employee's understanding of mudharabah and murabahah finance, and also the effect of intelligence, interests, talents, motivation, age, environment, education, experience and training toward the understanding of mudharabah and murabahah finance. The sample method used in this study is sampling purposive, i.e., BMT employee consists of Operations Manager, Marketing Manager, Finance Manager and Marketing who are in 60 respondents with a minimum term of 1 year. The analytical tool used is multiple regression analysis.

Based on the study and data analysis, it can be concluded that BMT employee understands on mudharabah finance. Intelligence, talent, and training signficantly effect to mudharabah finance, whereas interests, motivation, age, environment, education and experience insignificantly effect to mudharabah finance. It can be known that BMT employee understands on murabahah. Intelligence, talent, motivation and training significantly effect to murabahah, whereas interest, age, environment, education and experience insignificantly effect on the understanding of murabahah.
\end{abstract}

Keywords : Internal factor, External factor, Mudharabah, Murabahah

\section{PENDAHULUAN}

\section{Latar Belakang}

Fungsi dasar dari lembaga syarat mendapatkan keuntungan keuangan adalah sebagai lembaga (profit).

perantara atau mediasi yang Dalam sistem ekonomi yang menghubungkan antara pihak yang berparadigma Islami, transaksi kelebihan dana dengan pihak-pihak senantiasa harus dilandasi oleh aturan yang kekurangan dana. Berdasarkan hukum-hukum Islam (syariah), karena fungsi dasar tersebut maka secara transaksi adalah merupakan manifestasi otomatis pihak yang mempunyai amal manusia yang bernilai ibadah kelebihan dana akan melakukan dihadapan Allah SWT, sehingga dalam transaksi (transaction) dengan suatu Islam transaksi dapat dikategorikan 
menjadi dua yaitu transaksi yang halal dan transaksi yang haram (Shadr ; 2008). Transaksi halal adalah semua transaksi yang dibolehkan oleh Syariah Islamiyah, sedangkan transaksi haram adalah semua transaksi yang dilarang oleh Syariah Islamiyah.

Berdasarkan pemikiran diatas maka Majelis Ulama Indonesia (MUI) mengeluarkan fatwa tentang haramnya bunga bank pada tahun 2003. Perkembangan keuangan syariah di Indonesia mengalami kemajuan dengan diterbitkannya peraturan perundang-undangan yaitu Undangundang No. 21 tahun 2008 yang mengatur tentang operasional perbankan syariah di Indonesia dan diperbaharui dengan diterbitkannya Peraturan Bank Indonesia (PBI) No. $11 / 3 / \mathrm{PBI} / 2009$ yang mengatur tentang prosedur dan aturan dalam mendirikan kantor cabang.

Implikasi positif dari kebijakan pemerintah tersebut adalah berdirinya lembaga-lembaga keuangan syariah. Dalam perkembangannya sekarang ini, ada dua jenis lembaga keuangan syariah yaitu yaitu lembaga keuangan yang berupa bank dan non bank. Lembaga keuangan yang berupa bank terdiri dari Bank Umum Syariah (BUS) dan Unit Usaha Syariah (UUS) sedangkan lembaga keuangan syariah non bank antara lain berupa Unit Simpan Pinjam Syariah, Asuransi Syariah, Baitul Maal Wa Tamwil (BMT).

Baitul Maal Wa Tamwil (BMT) adalah lembaga keuangan non Bank yang beroperasi berdasarkan prinsip bagi hasil, didirikan oleh dan untuk masyarakat di suatu tempat atau daerah. BMT memiliki dua bidang kerja yaitu sebagai Lembaga Mal (Baitul Mal) dan sebagai Lembaga Tamwil (Baitul-Tamwil). Lembaga Mal dimaksudkan untuk menghimpun zakat, infak maupun sadaqah dan menyalurkannya kepada pihak-pihak yang berhak mendapatkan dalam bentuk pemberian tunai langsung maupun pinjaman modal tanpa bagi hasil. Dari pengertian tersebut jelaslah bahwa Baitul Mal ini bersifat nirlaba (sosial). Sedangkan lembaga Tamwil dimaksudkan untuk menghimpun dana masyarakat dalam bentuk saham, simpanan maupun deposito dan menyalurkannya sebagai modal usaha dengan bagi hasil antara pemodal, peminjam dan Lembaga BMT.

Sistem ekonomi Islam, bunga dapat dinyatakan sebagai riba yang "haram" hukumnya menurut syariah Islamiyah. Sebagai gantinya, sistem ekonomi Islam mengantinya dengan istilah "Bagi Hasil" yang dihalalkan oleh Syariah Islamiyah berdasarkan AlQur'an dan Al Hadist. Dalam praktiknya, ketentuan bagi hasil usaha harus ditentukan di muka atau pada awal akad/kontrak usaha disepakati oleh pihak-pihak yang akan melaksanakan akad. Porsi bagi hasil biasanya ditentukan dengan suatu perbandingan, misalnya 30 : 70 yang berarti bahwa hasil usaha yang dijalankan oleh mitra usaha akan didistribusikan sebesar 30\% kepada pemilik dana/investor (shahibul maal) dan sebesar $70 \%$ didistribusikan kepada pengelola dana (mudhorib).

Kehadiran BMT demikian penting dirasakan oleh masyarakat sebagai lembaga keuangan alternatif disamping perbankan dan lembaga keuangan lainnya. Dengan prinsip bagi hasil yang dioperasikan dengan sistem syariah, serta perkembangan menunjukan bahwa minat masyarakat terhadap lembaga keuangan syariah meningkat, maka kehadiran BMT menjadi alternative yang tidak bisa dianggap kecil. Namun demikian kondisi persaingan BMT dengan Bank 
Konvensional maupun dengan BPR yang demikian ketat mendorong untuk mencari strategi yang tepat dalam mengembangkan BMT dengan kinerja dan sumber daya yang dimiliki.

BMT menawarkan beberapa pilihan produk untuk nasabah diantaranya adalah pembiayaan Mudharabah dan Murabahah. Pembiayaan Mudharabah adalah akad kerjasama usaha antara shahibul maal (pemilik dana) dan Mudharib (pengelola dana) dengan nisbah bagi hasil menurut kesepakatan dimuka, jika usaha mengalami kerugian maka seluruh kerugian ditanggung oleh pemilik dana, kecuali jika ditemukan adanya kelalaian atau kesalahan oleh pengelola dana, seperti penyelewengan, kecurangan, dan penyalahgunaan dana.

Murabahah adalah transaksi penjualan barang dengan menyatakan harga perolehan dan keuntungan (margin) yang disepakati oleh penjual dan pembeli. Dalam transaksi murabahah, BMT bisa bertindak sebagai penjual dan pembeli. Sebagai penjual apabila BMT menjual barang kepada nasabah, sedangkan sebagai pembeli apabila BMT membeli barang kepada supplier untuk dijual kepada nasabah.

Menurut pandangan Islam, kepemilikan manusia atas sumber daya ekonomi tidak terjadi secara mutlak, tetapi manusia hanya diserahi tugas mengelola dan menggunakan saja. Hal ini berarti manusia hanya memiliki fungsi khilafah terhadap sumber daya ekonomi (Shadr , 2008). Kedudukan manusia sebagai khalifah Allah, berimplikasi bahwa dalam mengelola sumber daya sesungguhnya manusia bekerja mengelola sumber daya dengan cara benar dan mengemban amanah Allah untuk maksud kemaslahatan manusia keseluruhan.
Berdirinya BMT di Kabupaten Kebumen dimulai sejak tahun 1996 dengan 6 buah BMT, sampai dengan tahun 2013 menurut catatan Ketua Asosiasi BMT Kabupaten Kebumen sudah mencapai 45 buah BMT. Perkembangan BMT yang begitu pesat di Kabupaten Kebumen ternyata tidak diimbangi dengan peningkatan sumber daya manusia yang dimilki.

Dilihat dari tingkat pendidikan karyawan sebagian besar berpendidikan Sekolah Menengah (SMA dan SMK), untuk meningkatkan sumber daya manusia yang dimiliki maka BMT berinisiatif mengirimkan karyawannya untuk diberikan training atau pelatihan tentang operasional BMT. Menurut Prof.Dr.H. Amir Mualim (2006) menyatakan bahwa kegagalan pengelolaan BMT karena kurangnya persiapan sumber daya manusia (SDM) pengelola, baik dari sisi pengetahuan atau keterampilan dalam mengelola BMT dan lemahnya pengawasan pada pengelola terutama dalam manajemen.

Muhammad (2006) dalam Jurnal Ekonomi dan Bisnis Indonesia Vol. 21, No.3, 2006 hal 222 " Atribut Proyek dan Mudharib Dalam Pembiayaan Mudharabah Pada Bank Syari'ah di Indonesia menyatakan bahwa kesenjangan antara teori dengan realitas mekanisme operasi produk yang berbasis profit and loss sharing (PLS) ini dipengaruhi oleh faktor internal dan eksternal bank syariah. Secara internal kalangan perbankan belum memahami secara baik tentang konsep dan prkatek mudharabah. Tetapi dalam penelitian tersebut tidak menyebutkan faktor internal dan eksternal yang berhubungan dengan pemahaman.

Murtiyani (2007) menyatakan bahwa pemahaman manajer pada operasi perbankan Islam merupakan faktor 
utama bagi keberhasilan lembaga perbankan Islam, sebab merupakan faktor utama bagi seorang manajer dalam aplikasi amalan perbankan Islam. Dengan tingkat pemahaman manajer yang tinggi sepatutnya akan berpengaruh kepada tingkat kepatuhan syariah yang semakin tinggi bagi tingkatan kepatuhan syariah pada perbankan Islam.

Berdasarkan uraian diatas, peneliti akan meneliti tingkat pemahaman karyawan BMT terhadap pembiayaan mudharabah dan murabahah serta faktor-faktor yang mempengaruhi pemahaman yang berasal dari faktor internal intelegensi, minat, bakat, motivasi, dan usia serta faktor eksternal lingkungan, pendidikan, pengalaman pelatihan

\section{Perumusan Masalah}

Dari uraian diatas peneliti merumuskan pertanyaan-pertanyaan penelitian sebagai berikut :

1. Bagaimana tingkat pemahaman karyawan BMT pembiayaan mudharabah dan murabahah?

2. Apakah intelegensi karyawan BMT berpengaruh terhadap pemahaman pembiayaan mudharabah dan murabahah?

3. Apakah minat karyawan BMT berpengaruh terhadap pemahaman pembiayaan mudharabah dan murabahah?

4. Apakah bakat karyawan BMT berpengaruh terhadap pemahaman pembiayaan mudharabah dan murabahah?

5. Apakah motivasi karyawan BMT berpengaruh terhadap pemahaman pembiayaan mudharabah dan murabahah?

6. Apakah usia karyawan BMT berpengaruh terhadap pemahaman pembiayaan mudharabah dan murabahah?
7. Apakah lingkungan karyawan BMT berpengaruh terhadap pemahaman pembiayaan mudharabah dan murabahah?

8. Apakah pendidikan karyawan BMT berpengaruh terhadap pemahaman pembiayaan mudharabah dan murabahah?

9. Apakah pengalaman karyawan BMT berpengaruh terhadap pemahaman pembiayaan mudharabah dan murabahah?

10. Apakah pelatihan karyawan BMT berpengaruh terhadap pemahaman pembiayaan mudharabah dan murabahah?

\section{Tujuan Penelitian}

Sejalan dengan rumusan masalah diatas, tujuan dari penelitian ini adalah:

1. Untuk mengetahui tingkat pemahaman karyawan BMT terhadap pembiayaan mudharabah dan murabahah

2. Untuk mengetahui pengaruh intelegensi karyawan BMT terhadap pemahaman pembiayaan mudharabah dan murabahah.

3. Untuk mengetahui pengaruh minat karyawan BMT terhadap pemahaman pembiayaan mudharabah dan murabahah.

4. Untuk mengetahui pengaruh bakat karyawan BMT terhadap pemahaman pembiayaan mudharabah dan murabahah.

5. Untuk mengetahui pengaruh motivasi karyawan BMT terhadap pemahaman pembiayaan mudharabah dan murabahah.

6. Untuk mengetahui pengaruh usia karyawan BMT terhadap pemahaman pembiayaan mudharabah dan murabahah.

7. Untuk mengetahui pengaruh lingkungan karyawan BMT 
terhadap pemahaman pembiayaan mudharabah dan murabahah.

8. Untuk mengetahui pengaruh pendidikan karyawan BMT terhadap pemahaman pembiayaan mudharabah dan murabahah.

9. Untuk mengetahui pengaruh pengalaman karyawan BMT terhadap pemahaman pembiayaan mudharabah dan murabahah.

10. Untuk mengetahui pengaruh pelatihan karyawan BMT terhadap pemahaman pembiayaan mudharabah dan murabahah

\section{KAJIAN PUSTAKA DAN PENGEMBANGAN HIPOTESIS}

\section{Pembiayaan Mudharabah}

Pengertian mudharabah

berasal dari kata dharb yang berarti memukul atau berjalan. Pengertian memukul atau berjalan ini maksudnya adalah proses seseorang memukulkan kakinya dalam menjalankan usaha.

Mudharabah atau qiradh termasuk dalam kategori syirkah. Di dalam Al-Quran, kata mudharabah tidak disebutkan secara jelas dengan istilah mudharabah. Al-Quran hanya menyebutkan secara musytag dari kata dharaba.

\section{Murabahah}

Menurut Muhammad dalam bukunya Sistem dan Prosedur Operasional Bank Syariah (2008:103) pengertian secara fiqih murabahah adalah akad jual beli atas barang tertentu, dimana penjual menyebutkan dengan jelas barang yang diperjualbelikan, termasuk harga pembelian barang kepada pembeli, kemudian ia mensyaratkan atasnya laba/keuntungan dalam jumlah tertentu. Sedangkan pengertian secara teknis perbankan murabahah adalah akad jual beli barang sebesar harga pokok barang ditambah margin keuntungan yang disepakati.

Dewan Syari'ah Nasional MUI pengertian murabahah adalah menjual suatu barang dengan menegaskan harga belinya kepada pembeli dan pembeli membayarnya dengan harga yang lebih sebagai laba.

Pembayaran atas akad jual beli dapat dilakukan secara tunai maupun kredit. Hal yang membedakan murabahah dengan jual beli lainnya adalah penjual harus memberitahukan kepada pembeli harga barang pokok yang dijualnya serta jumlah keuntungan yang diperoleh

\section{Pengaruh intelegensi terhadap pemahaman pembiayaan muhdarabah dan murabahah}

Intelegensi merupakan daya atau potensi seseorang untuk memahami suatu aktivitas atau perilaku yang merupakan perwujudan dari daya atau potensi. Seorang yang mempunyai intelegensi tinggi akan mudah menerima informasi baru sehingga menimbulkan pemahaman dan perilaku baru.

Elfina Yenti dalam penelitiannya menyatakan bahwa perilaku seseorang mempengaruhi pemahaman. Setiap ada penambahan perilaku yang positif pemahaman seseorang juga akan bertambah.

Nugraeni \& Sulistyawati (2012) dalam Penelitiannya Pemahaman terhadap IFRS menjelaskan bahwa ada pengaruh yang signifikan antara kecerdasan Intelektual dengan Pemahaman terhadap IFRS.

Berdasarkan hal tersebut diatas maka hipotesisnya adalah sebagai berikut :
H1 : Intelegensi berpengaruh terhadap pemahaman pembiayaan mudharabah
$\mathrm{H} 2$ : Intelegensi berpengaruh 
terhadap

Murabahah

\section{Pengaruh minat terhadap pemahaman muhdarabah dan murabahah}

Minat adalah keinginan setelah melihat, mengamati dan membandingkan dengan kebutuhan yang diinginkan. Seseorang yang mempunyai minat besar akan berusaha mencari informasi sebanyak-banyaknya sehingga informasi yang dibutuhkan akan dengan mudah ia dapatkan. Seorang yang mempunyai minat tinggi mudah memahami persoalan dari informasi yang ia dapatkan.

Evitasari (2010) dalam penelitian Pengaruh Pengendalian Diri, Motivasi dan Minat Belajar terhadap pemahaman Akuntansi menjelaskan bahwa ada pengaruh yang signifikan antara minat belajar dengan pemahaman akuntansi.

Nugraeni \& Sulistyawati (2012) dalam Penelitian Faktor-faktor yang mempengaruhi Pemahaman terhadap IFRS menjelaskan bahwa ada pengaruh yang signifikan antara minat dengan Pemahaman terhadap IFRS.

Berdasarkan hal tersebut diatas maka hipotesisnya adalah sebagai berikut :

H3 : Minat berpengaruh terhadap pemahaman pembiayaan mudharabah

H4 : Minat berpengaruh terhadap pemahaman murabahah

\begin{tabular}{|c|c|c|}
\hline $\begin{array}{l}\text { Pengaruh } \\
\text { pemahaman }\end{array}$ & $\begin{array}{l}\text { bakat te } \\
\text { pem }\end{array}$ & $\begin{array}{l}\text { chadap } \\
\text { iayaan }\end{array}$ \\
\hline uhdarabah da & nurabaha & \\
\hline Alek & Sobur & (2011) \\
\hline mendevinisikan & bakat & $\mathrm{ada}$ \\
\hline kemampuan & alamiah & atuk \\
\hline $1 \cdot 1$ & pengetahuan & \\
\hline romnilon & ig relatif bisa & 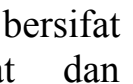 \\
\hline
\end{tabular}

kemampuan menentukan prestasi seseorang.

Orang yang berbakat akan mampu mencapai prestasi tinggi dalam bidang tertentu, jadi prestasi merupakan perwujudan dari bakat dan kemampuan. Prestasi yang sangat menonjol dalam salah satu bidang mencerminkan bakat yang unggul dalam bidang tersebut.

Seorang yang berbakat akan berusaha mencari informasi agar bakat yang dimiliki bisa tersalurkan sesuai dengan keinginannya, dengan bakat yang dimiliki seseorang akan mudah memahami persoalan yang dihadapinya.

$$
\begin{aligned}
& \text { Berdasarkan hal tersebut } \\
& \text { diatas maka hipotesisnya adalah }
\end{aligned}
$$

\section{Pengaruh motivasi terhadap pemahaman pembiayaan muhdarabah dan murabahah}

Harold Konnts dan kawankawan (1980) dalam Alek Sobur (2011) motivasi merupakan suatu keadaan dari dalam yang memberi kekuatan, yang menggiatkan, atau yang menggerakan, sehingga disebut penggerakan atau motivasi dan yang mengarahkan atau menyalurkan perilaku ke arah tujuan. Seorang yang mempunyai motivasi besar akan berusaha mendapatkan informasi yang aktual agar keinginannya terpenuhi, dengan motivasi yang dimiliki seseorang akan mudah memahami masalah yang dihadapinya.

$$
\text { Yunani (2010) dalam }
$$

penelitian Pengaruh Kecerdasan

Emosional terhadap Tingkat

Pemahaman Akuntansi menjelaskan 
bahwa motivasi berpengaruh secara signifikan terhadap tingkat pemahaman akuntansi.

Berdasarkan hal tersebut diatas maka hipotesisnya adalah sebagai berikut :

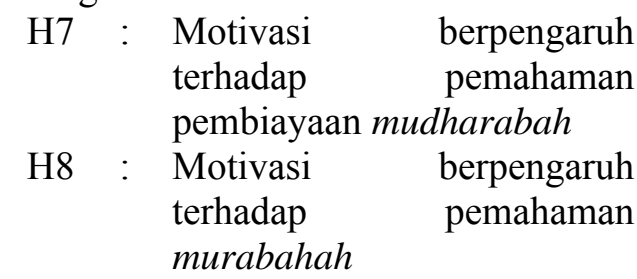

\section{Pengaruh usia terhadap pemahaman pembiayaan muhdarabah dan murabahah}

Destria (2010) menjelaskan bahwa Semakin cukup umur, tingkat kematangan dan kekuatan seseorang akan lebih matang dalam berfikir dan bekerja. Kemudian dari segi kepercayaan masyarakat seorang akan lebih matang dalam berfikir dan bekerja, hal ini disebabkan karena pengalaman dan kematangan jiwa. Dengan usia yang memadai seseorang akan mudah memahami persoalan yang ada.

Hayati (2008) dalam penelitian Pemahaman Praktisi BMT di Yogyakarta Terhadap PSAK No. 59 Pengakuan dan Pengukuran Produk Funding Menjelaskan bahwa usia mempunyai hubungan yang signifikan terhadap Pemahaman Produk PSAK No 59.

Berdasarkan hal tersebut diatas maka hipotesisnya adalah sebagai berikut :

H9 : Usia berpengaruh terhadap pemahaman pembiayaan mudharabah

H10 : Usia berpengaruh terhadap pemahaman murabahah

\section{Pengaruh lingkungan terhadap pemahaman pembiayaan muhdarabah dan murabahah}

merupakan salah satu filsuf yang beraliran empirisme, aliran ini mengemukakan bahwa anak yang baru lahir laksana kertas yang putih bersih. Kertas putih dapat ditulis dengan tinta warna apapun, sedangkan warna tinta diumpamakan sebagai lingkungan, yang akan berpengaruh terhadapnya. Kesimpulan dari aliran empirisme adalah perkembangan seseorang sepenuhnya tergantung dari faktor lingkungan.

Fudyartanta

menjelaskan bahwa kegiatan individu mempunyai lingkungan aktivitas yang sagat luas, tetapi dalam bahasa seharihari diartikan sebagai kegiatankegiatan yang tampak oleh pengamatan, atau dengan perkataan lain yang terwujud dalam perbuatan atau tingkah laku individu dalam hubungan dengan lingkungan. Individu harus menyesuaikan dengan lingkungan karena penyesuaian bukanlah aktivitas yang statis, tetapi dinamis, artinya ke arah keadaan yang lebih baik sejauh mungkin.

Individu dapat menyesuaikan diri kepada alam sekitar (lingkungan), tetapi pada suatu ketika lingkungan disesuaikan kepada individu. Lingkungan yang memadai akan memudahkan individu dalam memperoleh informasi sehingga akan dengan mudah memahami permasalahan yang ada.

Ridho (2009) dalam penelitian Pengaruh lingkungan masyarakat terhadap motivasi belajar siswa SMK Audio vidio menjelaskan bahwa lingkungan masyarakat berpengaruh secara signifikan terhadap motivasi belajar. 


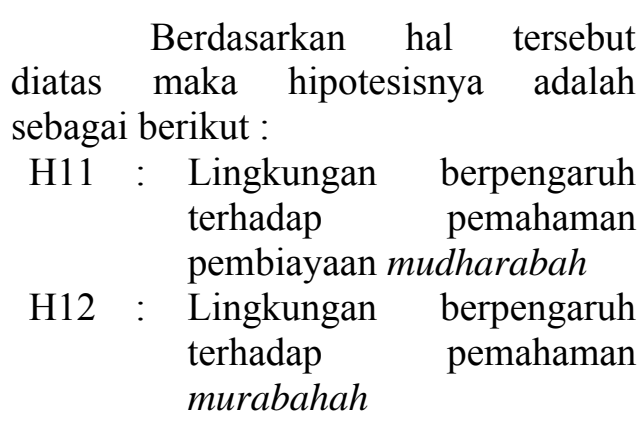

Pengaruh pendidikan terhadap pemahaman pembiayaan muhdarabah dan murabahah

Pendidikan sangatlah penting dalam kehidupan manusia. Manusia dapat menjadi manusia karena memanusiakan diri, yaitu terjadi karena proses pendidikan. Pendidikan menurut Ki Fudyartana (2010) adalah tindakan budaya sadar dan sistimatis yang ditujukan kepada seseorang agar dapat mengembangkan potensi yang ada padanya dan untuk mengenalkan nilainilai budaya serta sifat-sifat dan kecakapan sesuai dengan tujuan pendidikan. Dengan pendidikan seseorang akan mendapatkan informasi dan memahami persaoalan yang ada.

Hayati (2008) dalam penelitian Pemahaman Praktisi BMT di Yogyakarta Terhadap PSAK No. 59 Pengakuan dan Pengukuran Produk Funding Menjelaskan bahwa Pendidikan mempunyai hubungan yang signifikan terhadap Pemahaman Produk PSAK No 59.

$$
\text { Efizon A (2008) dalam }
$$
penelitian Faktor-faktor yang mempengaruhi pemahaman masyarakat tentang wakaf uang menjelaskan bahwa tingkat pendidikan berpengaruh secara signifikan terhadap pemahaman masyarakat tentang wakaf uang.

Utomo (2012) dalam penelitian Analisis Pengaruh Pendidikan dan Pelatihan terhadap Pemahaman Akuntansi menjelaskan bahwa Pendidikan berpengaruh secara signifikan terhadap pemahaman Akuntansi.

Sudarman (2012) dalam penelitian Analisis Tingkat Pemahaman Laporan Keuangan Bagi Mahasiswa Jurusan Akuntansi ditinjau dari Pendidikan, Pelatihan dan Ketekunan menjelaskan bahwa pendidikan berpengaruh secara signifikan terhadap pemahaman laporan keuangan bagi mahasiswa jurusan akuntansi.

Berdasarkan hal tersebut diatas maka hipotesisnya adalah sebagai berikut :

$$
\begin{array}{rlr}
\text { H13 : } & \text { Pendidikan } & \text { berpengaruh } \\
& \text { terhadap } & \text { pemahaman } \\
\text { pembiayaan } & \text { mudharabah } \\
\text { H14 : } & \begin{array}{l}
\text { Pendidikan } \\
\text { terhadap }
\end{array} & \text { berpengaruh } \\
& \text { murabahah } &
\end{array}
$$
H14 : Pendidikan berpengaruh terhadap pemahaman murabahah

\section{Pengaruh pengalaman terhadap pemahaman pembiayaan muhdarabah dan murabahah}

Loehoer (2002) menjelaskan bahwa pengalaman merupakan akumulasi gabungan dari semua yang diperoleh melalui berhadapan dan berinteraksi secara berulang-ulang dengan sesama benda alam, keadaan, gagasan, dan penginderaan. Devinisi pengalaman kerja yang lebih spesifik dikemukakan oleh Ranupandojo (1984) bahwa pengalaman kerja adalah ukuran tentang lama waktu atau masa kerja yang telah ditempuh seseorang dapat memahami tugas-tugas suatu pekerjaan dan telah melaksanakan dengan baik.

Dari pengertian diatas dapat disimpulkan bahwa pengalaman kerja adalah tingkat penguasaan pengetahuan serta keterampilan seseorang dalam pekerjaannya yang dapat diukur dari masa kerja dan dari tingkat pengetahuan dan ketermapilan yang dimiliki. Sehingga dapat disimpulkan 
bahwa pengalaman seseorang akan mempengaruhi pemahaman.

Hayati (2008) dalam

penelitian Pemahaman Praktisi BMT di

Yogyakarta Terhadap PSAK No. 59

Pengakuan dan Pengukuran Produk

Funding Menjelaskan bahwa

Pengalaman mempunyai hubungan

yang signifikan terhadap Pemahaman

Produk PSAK No 59.

Cahyadi (2009) dalam

penelitian Pengaruh tingkat

Pendidikan, Masa Kerja, Pelatihan, dan

Posisi di Pemerintahan terhadap

Pemahaman Laporan Keuangan Daerah

menjelaskan bahwa masa kerja

(pengalaman) berpengaruh secara

signifikan terhadap Pemahaman

Laporan Keuangan Daerah.

Murtiyani (2010) dalam

penelitian yang berjudul Indek

Kepatuhan Syariah dan Faktor-faktor

yang mempengaruhinya pada Bank

Syariah di Indonesia menjelaskan bahwa pengalaman bekerja di Bank

Konvensional berpengaruh secara

signifikan terhadap pemahaman

Manajer.

Berdasarkan hal tersebut diatas maka hipotesisnya adalah sebagai berikut :

$\begin{array}{rlr}\text { H15 : } & \begin{array}{l}\text { Pengalaman } \\ \text { terhadap } \\ \text { pembiayaan }\end{array} \\ \text { Hudharabah } & \begin{array}{l}\text { memahaman } \\ \text { H16 : }\end{array} \\ & \begin{array}{l}\text { Pengalaman berpengaruh } \\ \text { terhadap } \\ \text { murabahah }\end{array}\end{array}$

\section{Pengaruh pelatihan terhadap pemahaman muhdarabah dan murabahah}

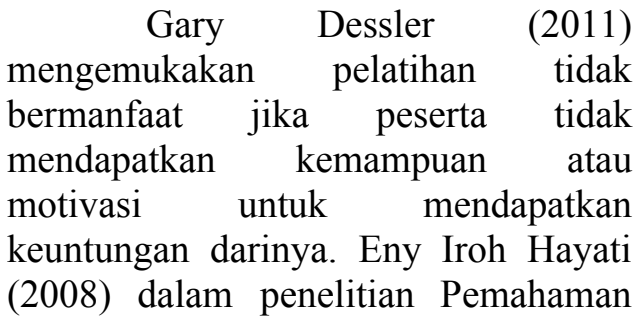

Praktisi BMT di Yogyakarta Terhadap PSAK No. 59 Pengakuan dan Pengukuran Produk Funding menjelaskan bahwa pelatihan mempunyai hubungan yang signifikan terhadap Pemahaman Produk PSAK No 59.

\begin{tabular}{llr}
\multicolumn{2}{c}{ Cahyadi (2009) dalam } \\
penelitian Pengaruh tingkat
\end{tabular} Pendidikan, Masa Kerja, Pelatihan, dan Posisi di Pemerintahan terhadap Pemahaman Laporan Keuangan Daerah menjelaskan bahwa Pelatihan berpengaruh secara signifikan terhadap Pemahaman Laporan Keuangan Daerah.

Utomo (2012) dalam penelitian yang berjudul Analisis Pengaruh Pendidikan dan Pelatihan terhadap pemahaman Akuntansi menjelaskan bahwa pelatihan berpengaruh secara signifikan terhadap pemahaman Akuntansi.

Sudarman dalam penelitian Analisis Tingkat Pemahaman Laporan Keuangan Bagi Mahasiswa Jurusan Akuntansi ditinjau dari Pendidikan, Pelatihan dan Ketekunan menjelaskan bahwa pelatihan berpengaruh secara signifikan terhadap pemahaman laporan keuangan bagi mahasiswa jurusan akuntansi.

Berdasarkan hal tersebut diatas maka hipotesisnya adalah sebagai berikut :

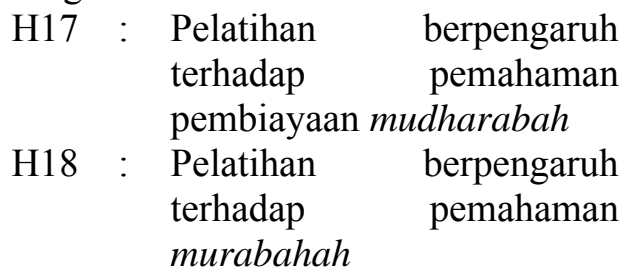

Dari hipotesis dan penelitian terdahulu maka model penelitian dan pengembangan hipotesisnya adalah seperti dalam gambar dibawah ini 


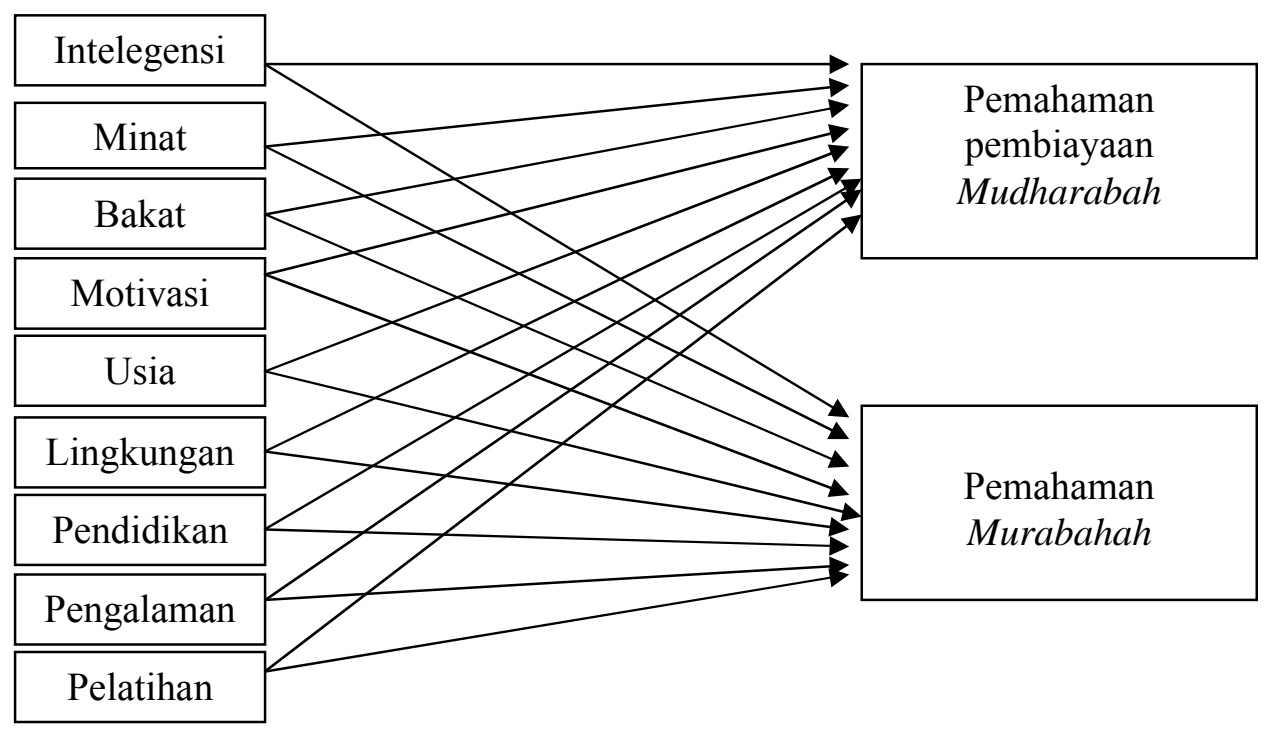

Gambar 2.1 Model Penelitian dan Pengembangan Hipotesis

\section{METODOLOGI PENELITIAN}

\section{Populasi dan Sample}

Populasi dalam penelitian ini adalah jumlah karyawan BMT yang tergabung dalam Asosiasi BMT sebanyak 73 karyawan. Jumlah sample yang diambil dalam penelitian ini ditentukan dengan pendapat Sugiyono (2010) dengan taraf kesalahan 5\% sehingga berjumlah 60 karyawan. Teknik sampling yang digunakan dalam penelitian ini adalah purposive sampling dengan kriteria Manajer Operasional, Manajer Pemasaran, Manajer Pembiayaan dan Marketing yang telah bekerja lebih dari 1 tahun.

\section{Analisis Regresi Berganda}

Garis regresi dalam penelitian ini adalah untuk mengetahui pengaruh faktor internal terhadap pemahaman mudharabah dan murabahah :

$\mathrm{Y} 1 \mathrm{a}=\alpha+\beta 1 \mathrm{X} 1+\beta 2 \mathrm{X} 2+\beta 3 \mathrm{X} 3+\beta 4 \mathrm{X} 4+$ $\beta 5 \times 5+\mathrm{e}$

$\mathrm{Y} 2 \mathrm{a}=\alpha+\beta 1 \mathrm{X} 1+\beta 2 \mathrm{X} 2+\beta 3 \mathrm{X} 3+\beta 4 \mathrm{X} 4+$ $\beta 5 \mathrm{X} 5+\mathrm{e}$

Y1a : Pemahaman Syarat dan
Rukun pembiayaan mudharabah

Y2a : Pemahaman syarat dan Rukun murabahah

$\alpha$ : Konstanta

$\beta 1 \quad$ : Koefisien Regresi

$\mathrm{X} 1$ : Intelegensi

$\mathrm{X} 2$ : Minat

$\mathrm{X} 3$ : Bakat

X4 : Motivasi

X5 : Usia

e : Standar error

Sedangkan untuk mengetahui pengaruh faktor eksternal terhadap pemahaman pembiayaan mudharabah dan murabahah garis regresinya adalah sebagai berikut :

$\mathrm{Y} 1 \mathrm{a}=\alpha+\beta 6 \mathrm{X} 6+\beta 7 \mathrm{X} 7+\beta 8 \mathrm{X} 8+\beta 9 \mathrm{X} 9+\mathrm{e}$ $\mathrm{Y} 2 \mathrm{a}=\alpha+\beta 6 \mathrm{X} 6+\beta 7 \mathrm{X} 7+\beta 8 \mathrm{X} 8+\beta 9 \mathrm{X} 9+\mathrm{e}$

Y1a : Pemahaman Syarat dan Rukun pembiayaan mudharabah

Y2a : Pemahaman syarat dan Rukun murabahah

$\alpha$ : Konstanta

$\beta \quad$ : Koefisien Regresi

X6 : Lingkungan

X7 : Pendidikan 


$$
\begin{array}{lll}
\text { X8 } & : & \text { Pengalaman } \\
\text { X9 } & : \text { Pelatihan } \\
\text { e } & : & \text { Standar error }
\end{array}
$$

\section{Model Pengujian Hipotesis}

a. Koefisien Determinasi

Koefisien determinasi $\left(\mathrm{R}^{2}\right)$ digunakan untuk mengukur seberapa jauh kemampuan model dalam menerangkan variasi variabel dependen atau terikat. Nilai koefisien determinasi adalah antara nol dan satu. Nilai $\mathrm{R}^{2}$ yang kecil, berarti kemampuan variabel-variabel bebas dalam menjelaskan variabel terikat sangat terbatas. Nilai yang mendekati satu, berarti variabel-variabel bebas memberikan hampir semua informasi yang dibutuhkan untuk memprediksi variasi variabel terikat.

b. Uji Signifikan Simultan (Uji Statistik

F)

Uji Statistik F pada dasarnya menunjukkan apakah semua variabel independen atau bebas yang dimasukkan dalam model mempunyai pengaruh secara bersama-sama terhadap variabel dependen/terikat. Hipotesis nol (Ho) yang hendak diuji adalah apakah semua parameter dalam model sama dengan nol, atau :

Ho : $\beta 1=\beta 2=\ldots \ldots \ldots \ldots=\beta \mathrm{k}=$ 0

Artinya, apakah semua variabel independen bukan merupakan penjelas yang signifikan terhadap variabel dependen. Hipotesis alternatifnya (HA) tidak semua parameter secara simultan sama dengan nol, atau :

На : $\beta 1 \neq \beta 2 \neq \ldots \ldots \ldots \ldots \neq \beta \mathrm{k} \neq$ 0

Artinya, semua variabel independen secara simultan merupakan penjelas yang signifikan terhadap variabel dependen.

Untuk menguji hipotesis ini digunakan statistik $\mathrm{F}$ dengan kriteria pengambilan keputusan sebagai berikut :

1. Quick look : bila nilai F lebih besar daripada empat maka Ho dapat ditolak pada derajat kepercayaan lima persen. Dengan kata lain kita menerima hipotesis alternatif, yang menyatakan bahwa semua variabel independen secara serentak dan signifikan mempengaruhi variabel dependen, atau :

2. Bila nilai signifikansi yang diperoleh lebih kecil dari 0,05 maka Ho ditolak dan Ha diterima. (Ghazali, 2005)

\section{HASIL DAN PEMBAHASAN}

\subsection{Uji Normalitas Data dan Asumsi Klasik}

Pengujian menunjukan bahwa data terdistribusi secara normal karena distribusi data residualnya terlihat mendekati garis normalnya. Begitu juga dengan scater plot, tampak titik yang menyebar kesemuanya yang menunjukan model ini berdistribusi normal.

$\begin{array}{lrr}\text { Uji asumsi klasik juga } \\ \text { menunjukan bahwa semua } & \text { variabel } \\ \text { bebas tersebut tidak } & \text { terjadi } \\ \text { heterokedastisitas dalam } & \text { varian } \\ \text { kesalahan, dan kesembilan } & \text { variabel } \\ \text { independen } & \text { tidak } & \text { terjadi }\end{array}$ multikolinearitas karena nilai $\mathrm{VIF}<10$. Dan uji autokorelasi menunjukan bahwa bahwa Durbin Watson berada di daerah no autokorelasi.

\subsection{Pengujian Hipotesis}

Hasil pengujian hipotesis

tampak pada tabel berikut ini 
Tabel 1

Hasil Uji F Faktor Internal Pembiayaan Mudharabah

ANOVA $^{\mathrm{b}}$

\begin{tabular}{|ll|r|r|r|r|r|}
\hline Model & & Sum of Squares & df & Mean Square & F & Sig. \\
\hline 1 & Regression & 1248,429 & 5 & 249,686 & 5,642 &, $000^{\text {a }}$ \\
& Residual & 2389,754 & 54 & 44,255 & & \\
& Total & 3638,183 & 59 & & & \\
\hline
\end{tabular}

a. Predictors: (Constant), X5Usia, X4Motivasi, X3Bakat, X1Intelegensi, X2Minat

b. Dependent Variable: Y1Mudharabah

Tabel 2

Hasil Perhitungan Regresi Faktor Internal Pembiayaan Mudharabah

Coefficients $^{\mathrm{a}}$

\begin{tabular}{|c|c|c|c|c|c|c|}
\hline \multirow{2}{*}{\multicolumn{2}{|c|}{ Model }} & \multicolumn{2}{|c|}{ Unstandardized Coefficients } & $\begin{array}{l}\text { Standardized } \\
\text { Coefficients }\end{array}$ & \multirow[b]{2}{*}{$t$} & \multirow[b]{2}{*}{ Sig. } \\
\hline & & $\mathrm{B}$ & Std. Error & Beta & & \\
\hline \multirow[t]{6}{*}{1} & (Constant) & 39,480 & 9,629 & & 4,100 &, 000 \\
\hline & X1Intelegensi & ,440 & , 177 & ,359 & 2,484 & ,016 \\
\hline & X2Minat &,- 085 & ,240 &,- 061 &,- 354 & ,724 \\
\hline & X3Bakat &, 587 & ,339 & ,253 & 1,735 & ,088 \\
\hline & X4Motivasi & ,166 & ,205 &, 110 & ,810 & ,422 \\
\hline & X5Usia & ,244 & ,467 & ,081 &, 523 & ,603 \\
\hline
\end{tabular}

a. Dependent Variable: Y1Mudharabah

Tabel 3

Hasil Uji F Faktor Internal Murabahah

ANOVA $^{\mathrm{b}}$

\begin{tabular}{|ll|r|r|r|r|r|}
\hline Model & & Sum of Squares & df & Mean Square & F & Sig. \\
\hline 1 & Regression & 1105,723 & 5 & 221,145 & 5,603 &, $000^{\mathrm{a}}$ \\
& Residual & 2131,260 & 54 & 39,468 & & \\
& Total & 3236,983 & 59 & & & \\
\hline
\end{tabular}

a. Predictors: (Constant), X5Usia, X4Motivasi, X3Bakat, X1Intelegensi, X2Minat

b. Dependent Variable: Y2Murabahah

Tabel 4

Hasil Perhitungan Regresi Faktor Internal Murabahah

Coefficients $^{a}$

\begin{tabular}{|ll|r|r|r|r|r|}
\hline Model & \multicolumn{2}{|c|}{$\begin{array}{c}\text { Standardized } \\
\text { Coefficients }\end{array}$} & \\
\cline { 3 - 5 } & & \multicolumn{2}{|c|}{ Unstandardized Coefficients } & \multicolumn{1}{c|}{ S } & \multicolumn{1}{c|}{ Sig. } \\
\hline 1 & (Constant) & 41,521 & 9,093 & & 4,566 &, 000 \\
& X1Intelegensi &, 474 &, 167 &, 410 & 2,830 &, 007 \\
& X2Minat &,- 425 &, 227 &,- 320 & $-1,874$ &, 066 \\
& X3Bakat &, 678 &, 320 &, 309 & 2,120 &, 039 \\
& X4Motivasi &, 456 &, 194 &, 319 & 2,349 &, 023 \\
& X5Usia &, 035 &, 441 &, 012 &, 080 &, 937 \\
\hline
\end{tabular}

a. Dependent Variable: Y2Murabahah 
Tabel 5

Hasil Uji F Faktor eksternal Pembiayaan Mudharabah

ANOVA $^{\mathrm{b}}$

\begin{tabular}{|ll|r|r|r|r|r|}
\hline Model & & Sum of Squares & \multicolumn{1}{|c|}{$\mathrm{df}$} & Mean Square & $\mathrm{F}$ & Sig. \\
\hline 1 & Regression & 1414,536 & 4 & 353,634 & 8,747 &, $000^{\mathrm{a}}$ \\
& Residual & 2223,647 & 55 & 40,430 & & \\
& Total & 3638,183 & 59 & & & \\
\hline
\end{tabular}

a. Predictors: (Constant), X9Pelatihan, X6Lingkungan, X8Pengalaman, X7Pendidikan

b. Dependent Variable: Y1Mudharabah

Tabel 6

Hasil Perhitungan Regresi Faktor Eksternal Pembiayaan Mudharabah

\begin{tabular}{|c|c|c|c|c|c|c|}
\hline \multicolumn{7}{|c|}{ Coefficients $^{\mathrm{a}}$} \\
\hline \multirow{2}{*}{\multicolumn{2}{|c|}{ Model }} & \multicolumn{2}{|c|}{ Unstandardized Coefficients } & $\begin{array}{l}\text { Standardized } \\
\text { Coefficients }\end{array}$ & \multirow[b]{2}{*}{$\mathrm{t}$} & \multirow[b]{2}{*}{ Sig. } \\
\hline & & $\mathrm{B}$ & Std. Error & Beta & & \\
\hline \multirow[t]{5}{*}{1} & (Constant) & 48,597 & 7,466 & & 6,509 &, 000 \\
\hline & X6Lingkungan & ,006 & 304 & ,003 & ,020 & ,984 \\
\hline & X7Pendidikan &, 140 & ,154 & ,153 &, 913 & ,365 \\
\hline & X8Pengalaman &, 525 & 311 & ,236 & 1,686 & 097 \\
\hline & X9Pelatihan & ,471 & , 195 & ,339 & 2,413 & ,019 \\
\hline
\end{tabular}

a. Dependent Variable: Y1Mudharabah

Tabel 7

Hasil Uji F Faktor eksternal Murabahah

ANOVA $^{\mathrm{b}}$

\begin{tabular}{|ll|r|r|r|r|r|}
\hline Model & & Sum of Squares & df & Mean Square & F & Sig. \\
\hline 1 & Regression & 1345,359 & 4 & 336,340 & 9,779 &, $000^{\text {a }}$ \\
& Residual & 1891,625 & 55 & 34,393 & & \\
& Total & 3236,983 & 59 & & & \\
\hline
\end{tabular}

a. Predictors: (Constant), X9Pelatihan, X6Lingkungan, X8Pengalaman, X7Pendidikan

b. Dependent Variable: Y2Murabahah

Tabel 8

Hasil Perhitungan Regresi Faktor Eksternal Murabahah

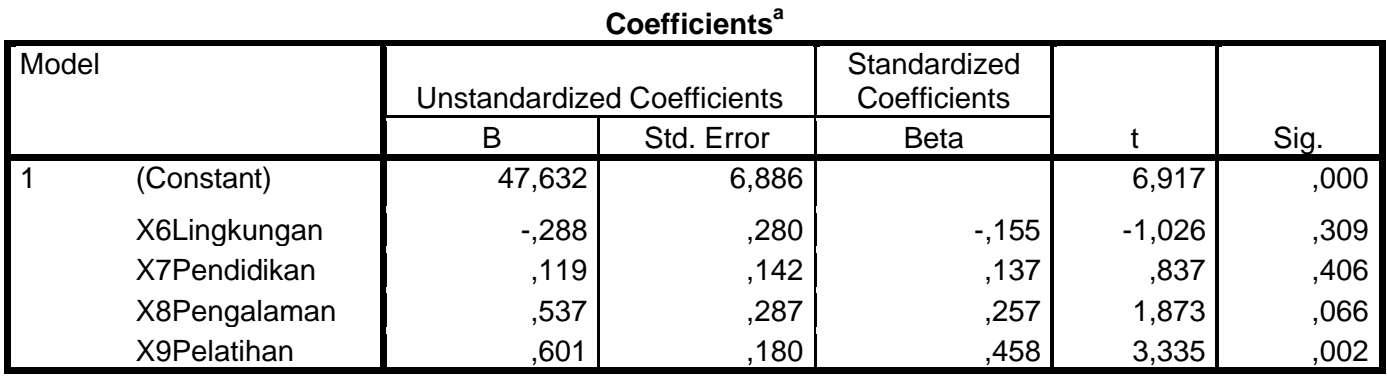

a. Dependent Variable: Y2Murabahah 
Pembahasan

Tingkat pemahaman karyawan terhadap pembiayaan mudharabah dan murabahah

Sesuai hasil jawaban responden terhadap butir-butir pertanyaan dalam kuesioner diketahui bahwa tingkat pemahaman karyawan tentang rukun dan syarat pembiayaan mudharabah sebesar 92,41\%, tidak paham sebanyak $3,80 \%$ dan netral $3,79 \%$. Hal ini sangat berbeda dengan tingkat pemahaman karyawan tentang murabahah, dari hasil kuesioner terhadap setiap butir pertanyaan diketahui bahwa 95,88\% menyatakan paham dengan syarat dan rukun murabahah, tidak paham sebanyak $1,14 \%$ dan netral $2,98 \%$.

Pengaruh intelegensi terhadap pemahaman pembiayaan mudharabah dan murabahah

Hipotesis 1 yang menyatakan intelegensi berpengaruh terhadap pemahaman pembiayaan mudharabah diterima dengan tingkat signifikansi sebesar 0,019. Sehingga dapat dikatakan bahwa intelegensi berpengaruh secara signifikan terhadap pemahaman pembiayaan mudharabah.

Hipotesis 2 yang menyatakan intelegensi berpengaruh terhadap pemahaman murabahah diterima dengan tingkat signifikansi sebesar 0,007. Sehingga dapat dikatakan bahwa intelegensi berpengaruh secara signifikan terhadap pemahaman murabahah.

Hasil penelitian ini konsisten dengan difinisi intelegensi menurut David Wechsler yang menyatakan bahwa kemampuan untuk bertindak secara terarah, berpikir secara rasional, dan menghadapi lingkungannya secara efektif.

Hasil penelitian ini sejalan dengan penelitian yang dilakukan oleh Nugraeni dan Sulistyawati (2012) bahwa kecerdasan intelektual

berpengaruh terhadap pemahaman IFRS.

\section{Pengaruh minat terhadap pemahaman pembiayaan mudharabah dan murabahah.}

Hipotesis 3 yang menyatakan minat berpengaruh terhadap pemahaman pembiayaan mudharabah diterima dengan tingkat signifikansi 0,745 . Sehingga dapat dikatakan bahwa minat berpengaruh tetapi tidak signifikan terhadap pemahaman pembiayaan mudharabah.

Hipotesis 4 yang menyatakan minat berpengaruh terhadap pemahaman murabahah diterima dengan tingkat sigifikansi sebesar 0,660. Sehingga dapat dikatakan bahwa minat berpengaruh tetapi tidak signifikan terhadap pemahaman murabahah.

Hasil penelitian ini sejalan dengan penelitian yang dilakukan oleh evitasari (2010) bahwa minat berpengaruh secara signifikan dengan pemahaman akuntansi dan penelitian yang dilakukan oleh Nugraeni dan Sulistyawati (2012) yang menyatakan bahwa minat berpengaruh terhadap pemahaman IFRS.

\section{Pengaruh bakat terhadap pemahaman pembiayaan mudharabah dan murabahah.}

Hipotesis 5 yang menyatakan bakat berpengaruh terhadap pemahaman pembiayaan mudharabah diterima dengan tingkat sigifikansi sebesar 0,042. Sehingga dapat dikatakan bahwa bakat berpengaruh secara signifikan terhadap pemahaman pembiayaan mudharabah.

Hipotesis 6 yang menyatakan bakat berpengaruh terhadap pemahaman murabahah diterima. dengan tingkat sigifikansi sebesar 0,039 . Sehingga dapat dikatakan bahwa 
bakat berpengaruh secara signifikan terhadap pemahaman murabahah.

Hasil penelitian ini konsisten dengan difinisi bakat menurut Alek Sobur (2011) bahwa seseorang yang berbakat akan berusaha mencari informasi agar bakat yang dimilikinya bisa tersalurkan sesuai keinginannya, dengan bakat yang dimiliki seseorang akan mudah memahami persoalan yang dihadapinya.

\section{Pengaruh motivasi terhadap pemahaman pembiayaan mudharabah dan murabahah.}

Hipotesis 7 yang menyatakan motivasi berpengaruh terhadap pemahaman pembiayaan mudharabah diterima dengan tingkat signifikansi sebesar 0,842. Sehingga dapat dikatakan bahwa motivasi berpengaruh tetapi tidak signifikan terhadap pemahaman pembiayaan mudharabah. Artinya perubahan keterampilan dan pengetahuan yang dimiliki karyawan dapat merubah pemahaman pembiayaan mudharabah.

Hipotesis 8 yang menyatakan motivasi berpengaruh terhadap pemahaman murabahah diterima dengan tingkat signifikansi sebesar 0,023 . Sehingga dapat dikatakan bahwa motivasi berpengaruh secara signifikan terhadap pemahaman murabahah. Dari sini dapat dikatakan bahwa perubahan motivasi karyawan akan merubah terhadap pemahaman murabahah.

Penelitian ini sejalan dengan penelitian yang dilakukan oleh Yunani (2010) bahwa motivasi berpengaruh terhadap tingkat pemahaman akuntansi.

Pengaruh usia terhadap pemahaman pembiayaan mudharabah dan murabahah

Hipotesis 9 yang menyatakan usia berpengaruh terhadap pemahaman pembiayaan mudharabah diterima dengan tingkat signifikansi 0,237 Sehingga dapat dikatakan bahwa usia berpengaruh tetapi tidak signifikan terhadap pemahaman pembiayaan mudharabah.

Hipotesis 10 yang menyatakan usia berpengaruh terhadap pemahaman murabahah diterima dengan tingkat signifikansi 0,937 Sehingga dapat dikatakan bahwa usia berpengaruh tetapi tidak signifikan terhadap pemahaman murabahah.

Hasil penelitian ini sejalan dengan Destria (2010) yang menyatakan bahwa semakin cukup umur tingkat kematangan dan kekuatan seseorang akan lebih matang dalam berfikir dan bekerja.

Hasil penelitian ini sejalan dengan Hayati (2008) dimana usia berpengaruh secara signifikan terhadap PSAK No. 59 pengakuan dan pengukuran produk funding.

\section{Pengaruh lingkungan terhadap pemahaman pembiayaan} mudharabah dan murabahah

Hipotesis 11 yang menyatakan lingkungan berpengaruh terhadap pemahaman pembiayaan mudharabah diterima dengan tingkat signifikansi sebesar 0,857. Sehingga dapat dikatakan bahwa lingkungan berpengaruh tetapi tidak signifikan terhadap pemahaman pembiayaan mudharabah.

Hipotesis 12 yang menyatakan lingkungan berpengaruh terhadap pemahaman murabahah diterima dengan tingkat signifikansi sebesar 0,309. Sehingga dapat dikatakan bahwa lingkungan berpengaruh tetapi tidak signifikan terhadap pemahaman murabahah.

Hasil penelitian ini sejalan dengan Salam (2003) yang berpendapat bahwa lingkungan berpengaruh terhadap pemahaman seseorang, jika orang hidup dalam lingkungan yang berpikiran luas maka tingkat pemahaman akan lebih baik dari pada 
orang yang tinggal di lingkungan orang yang berpikiran sempit.

\section{Pengaruh pendidikan terhadap pemahaman pembiayaan \\ mudharabah dan murabahah}

Hipotesis 13 yang menyatakan pendidikan berpengaruh terhadap pemahaman pembiayaan mudharabah diterima dengan tingkat signifikansi sebesar 0,356. Sehingga dapat dikatakan bahwa pendidikan berpengaruh tetapi tidak signifikan terhadap pemahaman pembiayaan mudharabah.

Hipotesis 14 yang menyatakan pendidikan berpengaruh terhadap pemahaman murabahah diterima dengan tingkat signifikansi sebesar 0,406 . Sehingga dapat dikatakan bahwa pendidikan berpengaruh tetapi tidak signifikan terhadap pemahaman murabahah.

Hasil penelitian ini berbeda dengan penelitian yang dilakukan oleh Usman (2007) yang menyatakan bahwa pendidikan tidak berpengaruh terhadap pemahaman makna biaya overhead pabrik.

Hasil penelitian ini sejalan dengan penelitian yang dilakukan oleh Hayati (2008), Efizon (2008), Cahyadi (2009) dan Utomo (2012) yang menyatakan bahwa pendidikan berpengaruh terhadap pemahaman.

Pengaruh pengalaman terhadap pemahaman pembiayaan mudharabah dan murabahah

Hipotesis 15 yang menyatakan pengalaman berpengaruh terhadap pemahaman pembiayaan mudharabah diterima dengan tingkat signifikansi sebesar 0,102. Sehingga dapat dikatakan bahwa pengalaman berpengaruh tetapi tidak signifikan terhadap pemahaman pembiayaan mudharabah.

Hipotesis 16 yang menyatakan pengalaman berpengaruh terhadap pemahaman murabahah diterima dengan tingkat signifikansi sebesar 0,066 . Sehingga dapat dikatakan bahwa pengalaman berpengaruh tetapi tidak signifikan terhadap pemahaman murabahah.

Hasil penelitian ini berbeda dengan penelitian yang dilakukan oleh Usman (2007) yang menyatakan bahwa pengalaman tidak berpengaruh terhadap pemahaman makna biaya overhead pabrik.

$\begin{array}{lrr}\text { Hasil Penelitian } & \text { sejalan } \\ \text { dengan Hayati } & (2008) & \text { dimana } \\ \text { pengalaman berpengaruh } & \text { secara }\end{array}$ signifikan terhadap pemahamn karyawan tentang PSAK No. 59 pengakuan dan pengukuran produk funding.

\section{Pengaruh pelatihan terhadap pemahaman pembiayaan mudharabah dan murabahah}

Hipotesis 17 yang menyatakan pelatihan berpengaruh terhadap pemahaman pembiayaan mudharabah diterima dengan tingkat signifikansi sebesar 0,019. Sehingga dapat dikatakan bahwa pelatihan berpengaruh secara signifikan terhadap pemahaman pembiayaan mudharabah.

Hipotesis 18 yang menyatakan pelatihan berpengaruh terhadap pemahaman murabahah diterima dengan tingkat signifikansi sebesar 0,002. Sehingga dapat dikatakan bahwa pelatihan berpengaruh secara signifikan terhadap terhadap pemahaman murabahah.

\section{KESIMPULAN DAN IMPLIKASI \\ Kesimpulan}

Berdasarkan hasil analisis yang dilakukan, maka simpulan yang dapat ditarik dari penelitian ini adalah

1. Karyawan BMT pada umumnya mempunyai pemahaman yang tinggi mengenai rukun dan syarat 
pembiayaan mudharabah dan murabahah. Berdasarkan kuisioner yang disebarkan $92,41 \%$ menyatakan paham terhadap pembiayaan mudaharah, Sedangkan untuk pemahaman murabahah responden menyatakan paham sebesar $95,88 \%$.

2. Intelegensi karyawan berpengaruh terhadap pemahaman pembiayaan mudharabah dan murabahah.

3. Minat karyawan berpengaruh tetapi tidak signifikan terhadap pemahaman pembiayaan mudharabah dan murabahah .

4. Bakat karyawan berpengaruh secara signifikan terhadap pemahaman pembiayaan mudharabah dan murabahah.

5. Motivasi karyawan berpengaruh tetapi tidak signifikan terhadap pemahaman pembiayaan mudharabah, tetapi motivasi karyawan berpengaruh secara signifikan terhadap pemahaman murabahah.

6. Usia karyawan berpengaruh tetapi tidak signifikan terhadap pemahaman pembiayaan mudharabah dan murabahah.

7. Lingkungan karyawan berpengaruh tetapi tidak signifikan terhadap pemahaman pembiayaan mudharabah dan murabahah.
8. Pendidikan karyawan berpengaruh tetapi tidak signifikan terhadap pemahaman pembiayaan mudharabah dan murabahah

9. Pengalaman karyawan berpengaruh tetapi tidak signifikan terhadap pemahaman pembiayaan mudharabah dan murabahah.

10. Pelatihan karyawan berpengaruh secara signifikan terhadap pemahaman pembiayaan mudharabah dan murabahah.

\section{Impikasi}

Hasil penelitian ini menunjukan bahwa dalam melakukan rekrutmen karyawan agar memperoleh sumber daya manusia yang optimal sebaiknya manajemen memperhatikan faktor internal dan faktor eksternal. Sedangkan untuk faktor eksternal pendidikan dan pelatihan bagi pengelola BMT harus lebih ditingkatkan.

\section{Keterbatasan}

Dari hasil pengolahan data yang dilakukan dengan analisis regresi berganda menggunakan SPSS 18 for windows, diperoleh hasil koefisien determinasi $\left(\mathrm{R}^{2}\right)$ yang masih sangat rendah sehingga masih banyak pengaruh faktor lain di luar penelitian yang tidak dimasukan dalam model penelitian.

\section{DAFTAR PUSTAKA}

Cahyadi D, 2009, Pengaruh Tingkat Pendidikan, Masa Kerja, Pelatihan dan Posisi di Pemerintahan terhadap Pemahaman Laporan Keuangan Daerah. Tesis. Universitas Diponegoro, Semarang. (Tidak dipublikasikan)

DSN MUI, 2000. Fatwa DSN MUI No:04/DSN-MUI/IV/2000 tentang Murabahah , 2000. Fatwa DSN MUI No:07/DSN-MUI/IV/2000 tentang Pembiayaan Mudharabah

Desler G, 2006 Manajemen Sumber Daya Manusia. Terjemahan oleh Paramita Rahayu. PT Indeks, Jakarta Barat

Destria D, 2010. Faktor-faktor yang Berhubungan Dengan Tingkat Pemahaman Terhadap Pesan Antenatal Care. Artikel Ilmiah. Universitas Diponegoro, Semarang. 
Evrizon A, 2008. Faktor-faktor yang Mempengaruhi Pemahaman Masyarakat Tentang Wakaf Uang. Tesis. Universitas Indonesia. (Tidak dipublikasikan).

E-book, 2007. Kamus Populer Keuangan dan Ekonomi Syariah. Pusat Komunikasi Ekonomi Syariah. Jakarta. , 2007. Menjawab Keraguan Umat Islam Terhadap Bank Syariah. Pusat Komunikasi Ekonomi Syariah. Jakarta. , 2008. Bank-ku Syariah. Pusat Komunikasi Ekonomi Syariah. Jakarta.

, 2008. Lembaga Bisnis Syariah. Pusat Komunikasi Ekonomi Syariah. Jakarta.

Evytasari AA, 2010. Pengaruh Pengendalian Diri, Motivasi, dan Minat Belajar terhadap Pemahaman Akuntansi. Jurnal. UPN Veteran Yogyakarta.

Fudyartanta K. 2010. Psikologi Umum. Pustaka Pelajar, Yogyakarta.

Ghozali I. 2005. Aplikasi Analisis Multivariat Dengan Program SPSS, Badan Penerbitan UNDIP. Semarang

Humayon \& Jhon, Lack Of Profit Loss Sharing In Islamic Banking: Management and Control Imbalance. International Journal Of Islamic Financial Services Vol.2 No. 2.

Hayati EI, 2008. Pemahaman Praktisi BMT di Yogyakarta Terhadap PSAK NO. 59 (Akuntansi Perbankan Syariah) Pengakuan dan Pengukuran Produk Funding. Jurnal . Universitas Islam Indonesia

Idris M, 2003. Analisis Tingkat Kesehatan Kinerja LKS-BMT.

Levin, Hansen, \& leverie, 2012. Toward Understanding New Sales Employees Participation in Marketing-Related Technology: Motivation, Voluntariness, and Past Performance. Journal of Personal Selling \& sales Management, vol. XXXII.

Muqorobin M, Theoritical Analysis of interest Abolition and Introducing ProfitLoss Sharing. Special Paper For Innaugurating the Centennial Mu'tamar of Muhammadiyah.

Mohsin M, 1995. Economics Of Small Business In Islam. Visiting Scholar Research Series No. 2.

Murtiyani S, 2007. Indek Kepatuhan Syariah dan Faktor-faktor Yang Mempengaruhinya Pada Bank Syariah Di Indonesia

Mu'allim A, 2006. Profesionalisme Sumber Daya Manusia Baitul Mal wa Tamwil. Jurnal. Fenomena Vol. 4 Universitas Islam Indonesia.

Muhamad, 2008. Sistem dan Prosedur Operasional Bank Syariah. UII Press Yogyakarta.

Mathis LR and JH Jackson, 2011. Human Resource Management. Terjemahan oleh Diana Angelica.. Salemba Empat, Jakarta Selatan.

Nawawi H, 2008. Manajemen Sumber Daya Manusia Untuk Bisnis yang Kompetitif. Gadjah Mada University Press Yogyakarta

Ngatirin, 2009. Analisis Implementasi Prinsip-prinsip Perjanjian Akad Mudharabah Pada Baitul Maal Wat Tamwil (BMT) Tumang Boyolali. Tesis. Universitas Sebelas Maret Surakarta.

Nugraeni D dan AI Sulistyawati. 2012. Faktor-faktor yang Mempengaruhi Pemahaman Terhadap IFRS. Jurnal. Juraksi Vol 1. Universitas Semarang. 
Raman T, 2009. Mudarabah and The Pakistan Perspective. International journal Islamic research and training institute Jeddah, Saudi Arabia

Rahayu E S dan IM Nuryata, 2010. Pembelajaran Masa Kini. Sekarmita Training and Publishing. Jakarta Timur.

Rifai NH, 2010. Pintar Ibadah. Lintas Media. Jombang

Salam Nur, 2003. Kesehatan Masyarakat Ilmu dan Seni. Salemba Medika. Jakarta

Skiner, Saunders \& Beresford, 2004. Toward a shared understanding of skill shortages: differng perceptions of training and development needs. International journal Emerald volume 46

Shadr M, 2008. Buku Induk Ekonomi Islam IqtishaDuna. Zahra Publishing House. Jakarta.

Sugiyono, 2010. Metode Penelitian Kuantitatif Kualitatif dan R\&D. Alfabeta. Bandung.

Sobur Alek, 2011. Psikologi Umum. CV Pustaka Setia. Bandung

Usman A, 2007. Pemahaman Makna Biaya Overhead Pabrik dan Pembebanannya Oleh Pengusaha Industri Rumah Tangga Pakaian Jadi Dari Tekstil di Kota Medan. Tesis. Universitas Sumatera Utara, Medan. (Tidak dipublikasikan).

Utomo HS, 2012. Analisis Pengaruh Pendidikan dan Pelatihan Terhadap Pemahaman Akuntansi. Jurnal. UPN Veteran. Jawa Timur

Warsono, S dan I Natalia, 2011. Akuntansi Pengantar 1. Sistem Penghasil Informasi Keuangan Adaptasi IFRS, ABPublishER Yogyakarta.

Yunani A. 2010. Pengaruh Kecerdasan Emosional terhadap Tingkat Pemahaman Akuntansi. Jurnal. Universitas Diponegoro Semarang 